\title{
Purification of Pox Viruses by Density Gradient Centrifugation
}

\author{
By H. T. ZWARTOUW, J. C. N. WESTWOOD AND G. APPLEYARD \\ Microbiological Research Establishment, Porton, Wilts, England
}

(Received 26 February 1962)

\begin{abstract}
SUMMARY
Rabbit pox virus grown in tissue culture cells and vaccinia virus grown on rabbit skin have been purified as follows. The virus was sedimented and washed once by centrifugation to provide a tenfold virus concentrate. This semi-purified material was layered on top of a sucrose density gradient and centrifuged to produce a zone of virus separated from zones of impurity. Sucrose was removed from the purified virus suspension by thorough washing in the centrifuge. About $40 \%$ of the original infectivity was recovered in the purified material which consisted almost entirely of virus particles when examined in the electron microscope. Control experiments indicated a maximum of $5 \%$ protein impurity. Almost complete separation of vaccinia haemagglutinin and virus was obtained.
\end{abstract}

\section{INTRODUCTION}

Viruses of the pox group are generally purified by the technique of differential centrifugation based on the work of Craigie (1932) and Hoagland, Smadel \& Rivers (1940) with vaccinia virus. Dawson \& McFarlane (1948) found that vaccinia virus prepared by differential centrifugation was impure and that subsequent flocculation of the virus with $\mathrm{M}-\mathrm{NaCl}$ eliminated the impurity. More recently, Gessler, Bender \& Parkinson (1956), used 'fluorocarbon' (trifluorotrichloroethane) treatment to purify vaccinia virus but Epstein (1958) snowed that centrifugation after fluorocarbon treatment sedimented impurity as well as the virus although a certain region of the sediment contained only virus. The haemagglutinin and infectious virus particles of vaccinia have been separated on columns of diethylaminoethyl-cellulose (DEAEcellulose; McCrea \& O'Loughlin, 1959) but the amount of virus recovered was not reported. Dumbell, Downie \& Valentine (1957) found that the infectivity titres of crude cowpox virus preparations were increased by treatment with trypsin although the infectivities of both purified cowpox virus and crude vaccinia virus were decreased. We attempted to purify rabbit pox virus, grown in cultivable cells, by the technique of differential centrifugation but the product was substantially contaminated with non-viral particles. The present work shows briefly that other published methods were also unsatisfactory for purifying rabbit pox virus and describes a method of purification by centrifugation in a sucrose density gradient.

\section{METHODS}

Crude rabbit pox virus. Confluent monolayer cultures containing about $5 \times 10^{7}$ ERK 1 cells (Westwood, Macpherson \& Titmuss, 1957) were infected with rabbit pox virus (Utrecht strain, which produces no haemagglutinin) and incubated with $50 \mathrm{ml}$. 


\section{H. T. Zwartouw, J. C. N. Westwood and G. Appleyard}

medium for $26 \mathrm{hr}$. at $37^{\circ}$. The medium (Westwood, Macpherson \& Titmus, 1957) contained $5 \%$ calf serum. The cultures were shaken to complete detachment of the cells from the glass and the cells separated from the medium by centrifuging at $200 \mathrm{~g}$ for $10 \mathrm{~min}$. The cells $\left(4 \times 10^{7}\right.$ cells $/ \mathrm{ml}$. $)$ were resuspended in phosphate buffered saline ( $\mathrm{pH} \mathrm{7 \cdot 3)}$ and disrupted to liberate the virus by ultrasonic treatment with a $500 \mathrm{~W}$. Soniclean Generator at $40 \mathrm{kcyc}$./sec. (Dawe Instruments Ltd., London). Large particles of cell debris were removed by centrifuging at $800 \mathrm{~g}$ for $5 \mathrm{~min}$.

Crude vaccinia virus. Vaccinia virus was grown on the skin of rabbits for $48 \mathrm{hr}$. as described by Hoagland et al. (1940). Coloured rabbits were as satisfactory as white rabbits. The skin scrapings of each rabbit were collected into $25 \mathrm{ml}$. of $0.004 \mathrm{M}-$ McIlvaine buffer ( $\mathrm{pH} \mathrm{7 \cdot 8)}$ containing $0.1 \%$ sodium azide to inhibit growth of contaminating organisms (buffer + azide). The suspension of crude virus was shaken with glass beads and then centrifuged at $800 \mathrm{~g}$ for $10 \mathrm{~min}$. to sediment the largest particles. The deposit was re-extracted by shaking with half the original volume of buffer + azide, centrifuged as before and the two supernatant fluids combined.

Protein estimation. Protein was measured by the method of Lowry, Rosebrough, Farr \& Randall (1951) and expressed as mg./ml.

Virus infectivity. Virus was titrated on chicken embryo chorioallantoic membranes as described by Westwood, Phipps \& Boulter (1957) and expressed as pock-forming units (pfu)/ml. or pfu/mg. protein.

Vaccinia virus haemagglutinin. Haemagglutinin was titrated in calcium magnesium saline containing $1 \%$ normal rabbit serum (Fenner, 1958); $0 \cdot 1 \mathrm{ml}$. volumes of serial twofold dilutions and $0.5 \%$ suspension of vaccinia sensitive fowl cells were mixed and left at room temperature $1 \mathrm{hr}$. Results were expressed as the reciprocal of the final dilution producing haemagglutination.

\section{Purification process}

Preliminary centrifugation. The virus was sedimented from the crude suspension by centrifugation in an angle rotor (Spinco Model $\mathrm{L}$ Ultracentrifuge) at 35,000 $\boldsymbol{g}$ for $30 \mathrm{~min}$. and the supernatant fluid, containing most of the protein, discarded. The deposit was resuspended in a volume equal to the original volume of buffer + azide and centrifuged in the same way. This washed deposit was resuspended in one-tenth of the original volume of buffer + azide and is referred to as semi-purified virus. Large volumes of crude vaccinia virus were satisfactorily centrifuged in the Spinco batch rotor no. 1600 at $30,000 \mathrm{~g}$ for $60 \mathrm{~min}$.

Centrifugation in sucrose density gradients. Lusteroid tubes $(3 \times 1 \mathrm{in}$.) were filled by layering successively from pipettes $6 \mathrm{ml}$. each of $60,50,40$ and $30 \%(\mathrm{w} / \mathrm{v})$ sucrose in buffer + azide followed by $6 \mathrm{ml}$. of semi-purified virus. The tubes were centrifuged at room temperature in the Spinco swinging bucket rotor no. SW25 at 39,000 $\mathrm{g}$ for $20 \mathrm{~min}$. and the rotor decelerated by using the brake. Purified virus formed an opalescent zone in the $50 \%(\mathrm{w} / \mathrm{v})$ sucrose layer with zones of impurity above and below.

Separation of zones in density gradients. The technique used for separating and removing zones from the centrifuge tube was a simplified and reversed procedure of the method described by Hogeboom \& Kuff (1954). The centrifuge tube was held in a clamp which could be slowly elevated by means of a screw. A perforated Perspex disk (thickness $\frac{1}{16}$ in., diameter slightly less than the centrifuge tube and with 
106 conically shaped holes of diameter $0.02 \mathrm{in}$. and $0.06 \mathrm{in}$. at the upper and lower surfaces of the disk, respectively) was clamped by a central stainless steel rod so that the disk entered the rising centrifuge tube. The level of the disk in the tube was successively adjusted to coincide with the boundaries of the required zones which were then easily removed from above with a pipette. Corresponding zones from all the gradients of one batch of semi-purified virus were then combined.

Final washing to remove sucrose. The purified virus in about $50 \%(\mathrm{w} / \mathrm{v})$ sucrose was diluted with 2 vol. of $0.004 \mathrm{M}-\mathrm{McIl}$ vaine buffer $(\mathrm{pH} \mathrm{7.8)}$ ) and centrifuged at $35,000 \mathrm{~g}$ for $60 \mathrm{~min}$. The deposited virus was washed twice with buffer and three times with water using a volume equal to the original sucrose suspension and centrifugation at $35,000 \mathrm{~g}$ for $30 \mathrm{~min}$. for each wash. The final deposit of virus was suspended in water and stored at $-60^{\circ}$.

\section{RESULTS}

Application of published methods to purification of rabbit pox virus

Flocculation with $\mathrm{NaCl}$. Salt was added to a suspension of rabbit pox virus, previously purified by centrifugation, to make $\mathrm{M}-\mathrm{NaCl}$. A precipitate formed slowly at $4^{\circ}$; it was collected after 3 days, washed with water and suspended in $0.004 \mathrm{M}$ phosphate buffer ( $\mathrm{pH} \mathrm{7 \cdot 6)}$ by ultrasonic treatment. Only $10 \%$ of the virus infectivity was recovered in the precipitated fraction. Of two samples of vaccinia virus treated similarly, one retained its infectivity but the other lost $99.5 \%$.

Table 1. Fluorocarbon treatment of crude rabbit pox virus

$\begin{array}{cccc}\begin{array}{c}\text { No. of } \\ \text { treatments }\end{array} & \begin{array}{c}\text { Infectivity } \\ \text { recovered } \\ (\%)\end{array} & \begin{array}{c}\text { Protein } \\ \text { recovered } \\ (\%)\end{array} & \begin{array}{c}\text { pfu/mg. } \\ \text { protein } \\ \left(\times 10^{-8}\right)\end{array} \\ 0 & 100 & 100 & 1.7 \\ 1 & 86 & 51 & 2.9 \\ 2 & 56 & 28 & 3.5 \\ 3 & 16 & 20 & 1.5 \\ 4 & 7 & 12 & 0.9\end{array}$

Treatment with fluorocarbon. After removing large particles of cell debris, crude rabbit pox virus suspension was homogenized with a half-volume of trifluorotrichloroethane (Arcton 113, I.C.I. Ltd., London) for $1 \mathrm{~min}$. The aqueous phase was separated by centrifugation and treated in the same way thrice more. Table 1 shows that a little purification of the crude virus was obtained at first but repeated treatment removed both virus and protein impurity from the material. When a single treatment was carried out by homogenizing a similar mixture for 20 min. with ultrasonic vibration, only $1 \%$ of the infectivity and $12 \%$ of the protein was recovered. The fluorocarbon method would have appeared more effective if the initial virus suspension had contained large particles of cell debris since these would have sedimented during the centrifugation following the fluorocarbon treatment. However, the large particles were easily removed by preliminary centrifugation of the crude virus and it was concluded that little advantage would be gained by including fluorocarbon treatment as a preliminary step in the purification of this material. 


\section{H. T. Zwartouw, J. C. N. Westwood and G. Appleyard}

Adsorption on $D E A E$ cellulose. Rabbit pox virus was retained by columns of DEAE-cellulose, but only about $5 \%$ of the infectivity could be eluted using $\mathrm{NaCl}$ up to $3 \mathrm{M}$ at $\mathrm{pH} 6,7$ or 8 . When the DEAE-cellulose was subsequently removed from the column and shaken with buffer, a further $10 \%$ of the infectivity was recovered suggesting that the virus had been retained mechanically in the column of DEAEcellulose.

Treatment with trypsin. Crude rabbit pox virus preparations were treated with $0.2 \%$ Difco 1:250 trypsin or 0.01\% Armour crystalline trypsin for $30 \mathrm{~min}$. at $20^{\circ}$. The effect on infectivity titres of the preparations varied from no change to a threefold increase. However, when the treated virus was sedimented and washed in the centrifuge, up to $99 \%$ of the infectivity was lost as compared with untreated control samples. Purified rabbit pox virus and purified vaccinia virus both lost infectivity when treated with $0.01 \%$ crystalline trypsin.

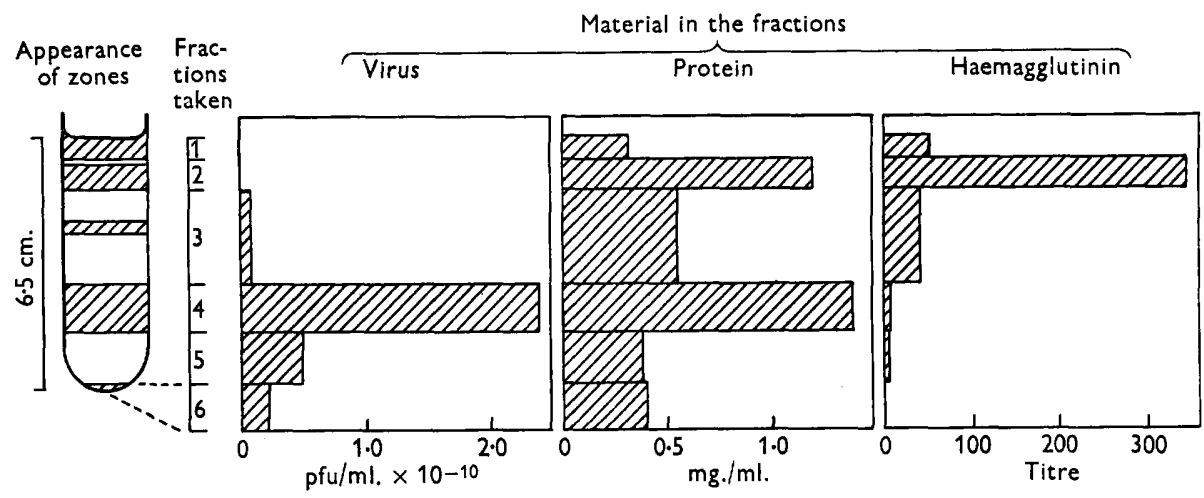

Fig. 1. Separation of vaccinia virus, haemagglutinin and protein impurity after centrifugation of semi-purified virus in a sucrose density gradient.

\section{Purification of rabbit pox and vaccinia viruses by density gradient centrifugation}

Separation in the sucrose density gradient. Essentially similar results were obtained with rabbit pox and vaccinia viruses but the latter provides a more detailed example since it was associated with haemagglutinin. Figure 1 illustrates the separation obtained after centrifuging a density gradient of semi-purified vaccinia virus. The majority of the virus was present in a well-defined opalescent zone separated from zones of protein impurity which contained relatively little virus. Almost complete separation of haemagglutinin and infective virus occurred. In some early experiments a large proportion of the virus sedimented below the typical virus zone into the deposit at the bottom of the density gradient. This appeared to be due to aggregation of the virus and did not occur when the following three conditions were adhered to: (1) the use of buffer at $\mathrm{pH} 7 \cdot 8$ to suspend the virus and to buffer the sucrose solution; (2) dispersion of the virus in the semi-purified suspension by ultrasonic treatment ( 5 min. with Dawe apparatus) just before placing it on the density gradient; (3) processing the semi-purified virus as soon as possible.

Yield from the purification process. Tables 2 and 3 show the range of results 
obtained in several purifications of rabbit pox and vaccinia virus. Most of the original infectivity was recovered in the semi-purified virus and about $50 \%$ in the virus zone of the sucrose density gradients. During the subsequent washing of purified virus to remove sucrose some infectivity was lost, probably because of aggregation of virus. The final washes with water caused pronounced macroscopic aggregation so that the virus would not remain suspended but settled out of the water on standing. The washed virus could be largely disaggregated by dilution into buffer and ultrasonic treatment so that stable suspensions were formed again. However, the infectivity/mg. protein was usually less than before washing, sometimes as much as threefold with vaccinia virus.

Table 2. Purification of rabbit pox virus; range of virus infectivity and protein recovered

$\begin{array}{lcccc}\begin{array}{c}\text { Virus } \\ \text { suspension }\end{array} & \begin{array}{c}\text { Relative } \\ \text { volume }\end{array} & \begin{array}{c}\text { Infectivity } \\ \text { recovered } \\ (\%)\end{array} & \begin{array}{c}\text { Protein } \\ \text { recovered } \\ (\%)\end{array} & \begin{array}{c}\text { pfu/mg. } \\ \text { protein } \\ \left(\times 10^{-8}\right)\end{array} \\ \text { Initial Crude* } & 120 & 100 & 100 & 0 \cdot 5-2 \\ \text { Semi-purified } & 12 & 75-100 & 5-13 & 10-20 \\ \text { Purified-in sucrose } & 13 & 40-70 & 0 \cdot 6-2 \cdot 5 & 31-61 \\ \text { Purified-washed } & 5 & 30-50 & 0 \cdot 5-1 \cdot 8 & \mathbf{3 3 - 4 5}\end{array}$

* Initial crude virus suspensions had $4 \times 10^{8}-1 \times 10^{9} \mathrm{pfu} / \mathrm{ml}$. and 5-10 $\mathrm{mg}$. protein $/ \mathrm{ml}$.

Table 3. Purification of vaccinia virus; range of virus infectivity and protein recovered

\begin{tabular}{|c|c|c|c|c|c|}
\hline $\begin{array}{c}\text { Virus } \\
\text { suspension }\end{array}$ & $\begin{array}{l}\text { Relative } \\
\text { volume }\end{array}$ & $\begin{array}{c}\text { Infectivity } \\
\text { recovered } \\
(\%)\end{array}$ & $\begin{array}{l}\text { Protein } \\
\text { recovered } \\
(\%)\end{array}$ & $\begin{array}{r}\text { pfu/mg. } \\
\text { protein } \\
\left(\times 10^{-8}\right)\end{array}$ & $\begin{array}{c}\text { Haemag- } \\
\text { glutinin/ } \\
\text { mg. } \\
\text { protein }\end{array}$ \\
\hline Initial crude* & 120 & 100 & 100 & $6-20$ & $5-10$ \\
\hline Semi-purified & 12 & $60-100$ & $6-16$ & $80-250$ & $30-100$ \\
\hline Purified-in sucrose & 14 & $30-70$ & $2-6$ & $100-240$ & $0-8$ \\
\hline Purified-washed & 10 & $15-60$ & $1 \cdot 5-4$ & $50-150$ & $0-8$ \\
\hline
\end{tabular}

* Initial crude virus suspensions had $3 \times 10^{9-1} \times 10^{10} \mathrm{pfu} / \mathrm{ml}$. and 5-7 mg. protein $/ \mathrm{ml}$.

Smadel, Pickels \& Shedlovsky (1938) demonstrated an osmotic effect of sucrose solutions on vaccinia virus by detecting changes in the virus sedimentation rate. The possibility that osmotic shock caused loss of virus infectivity during the washing to remove sucrose was tested. However, no loss of infectivity was detected when suspensions of virus in $60 \%(\mathrm{w} / \mathrm{v})$ sucrose solution were rapidly diluted. It was concluded that the osmotic changes which occurred when the purified virus in sucrose was diluted and centrifuged to wash away the sucrose did not cause the loss of infectivity but that aggregation of virus particles during the washing was the most probable cause.

\section{Purity of the virus preparations}

Electron microscopy. Plate 1 shows electron micrographs of typical purified samples of the two pox viruses. The samples were sprayed on to the support film and shadowed without further treatment (e.g. draining, washing, dialysis) in order that all impurities should be detectable. Dense areas containing clumps as well as 


\section{H. T. Zwartouw, J. C. N. Westwood and G. Appleyard}

isolated particles were selected for photography in preference to less dense areas, since the former were found to constitute a more exacting test for purity. In the rabbit pox preparations, apart from flattened particles resembling virus ghosts, non-viral debris was readily detectable but, nevertheless, constituted only a small proportion of the total material present. In the vaccinia preparations much less non-viral material was present.

Processing of control material. When uninfected tissue culture cells were disrupted and submitted to the virus purification process, the yield of protein in the fraction corresponding to rabbit pox virus was $0.025 \%$. Comparison with the yield of protein in the purified virus fraction from infected cells indicated a contamination of up to $5 \%$ of non-viral protein in the rabbit pox preparations. It was not possible to make a similar comparison for vaccinia virus grown on the skin of rabbits because comparable starting material could not be scraped from uninfected skins.

\section{DISCUSSION}

Centrifugation in density gradients has been used for purification of several viruses, notably those obtained from plants (Brakke, 1960). It has been customary to purify the relatively large pox viruses by differential centrifugation and it is clearly a refinement to employ the greater resolution obtainable by using a density gradient. In the method described here, sucrose was chosen to prepare the density gradients rather than a salt because the latter at high concentration aggregates and precipitates pox viruses. For the centrifugation it was essential to use a swinging bucket rotor since in an angle rotor the material could not sediment through the density gradient and was deposited on the outer side of the centrifuge tubes.

The infectivity/mg. protein of crude vaccinia virus was about ten-fold greater than that of crude rabbit pox virus. During purification, the infectivity/mg. protein of rabbit pox virus was increased more than that of vaccinia virus, but purified vaccinia virus in sucrose was still about four times more infective than similarly purified rabbit pox virus. In the final washed preparations, the difference was only about twofold since vaccinia virus suffered a greater loss of infectivity during the washing. Examination in the electron microscope and processing of uninfected control material both showed that the lower infectivity of purified rabbit pox virus was not due to the presence of large amounts of impurity. Presumably it was due to greater aggregation or to the presence of a higher proportion of 'non-infective' virus particles which did not give pocks in the infectivity assay used.

While treatment with reagents, such as fluorocarbon and trypsin, which act on protein are advantageous with very crude pox virus preparations, they are detrimental to the virus when large excesses of protein impurity have been removed. Suspensions of purified virus were susceptible to attack by contaminating bacteria and moulds, probably due to protease action in a similar manner to trypsin. Growth of contaminating organisms and consequent possible loss of virus infectivity was minimized by incorporating $0.1 \%$ sodium azide in the virus suspensions during purification and by storing the purified material at -60 .

The authors wish to thank Mr D. H. J. Titmuss and Mr D. J. Algar for valuable technical assistance. 
Journal of General Microbiology, Vol. 29, No. 3

Plate 1

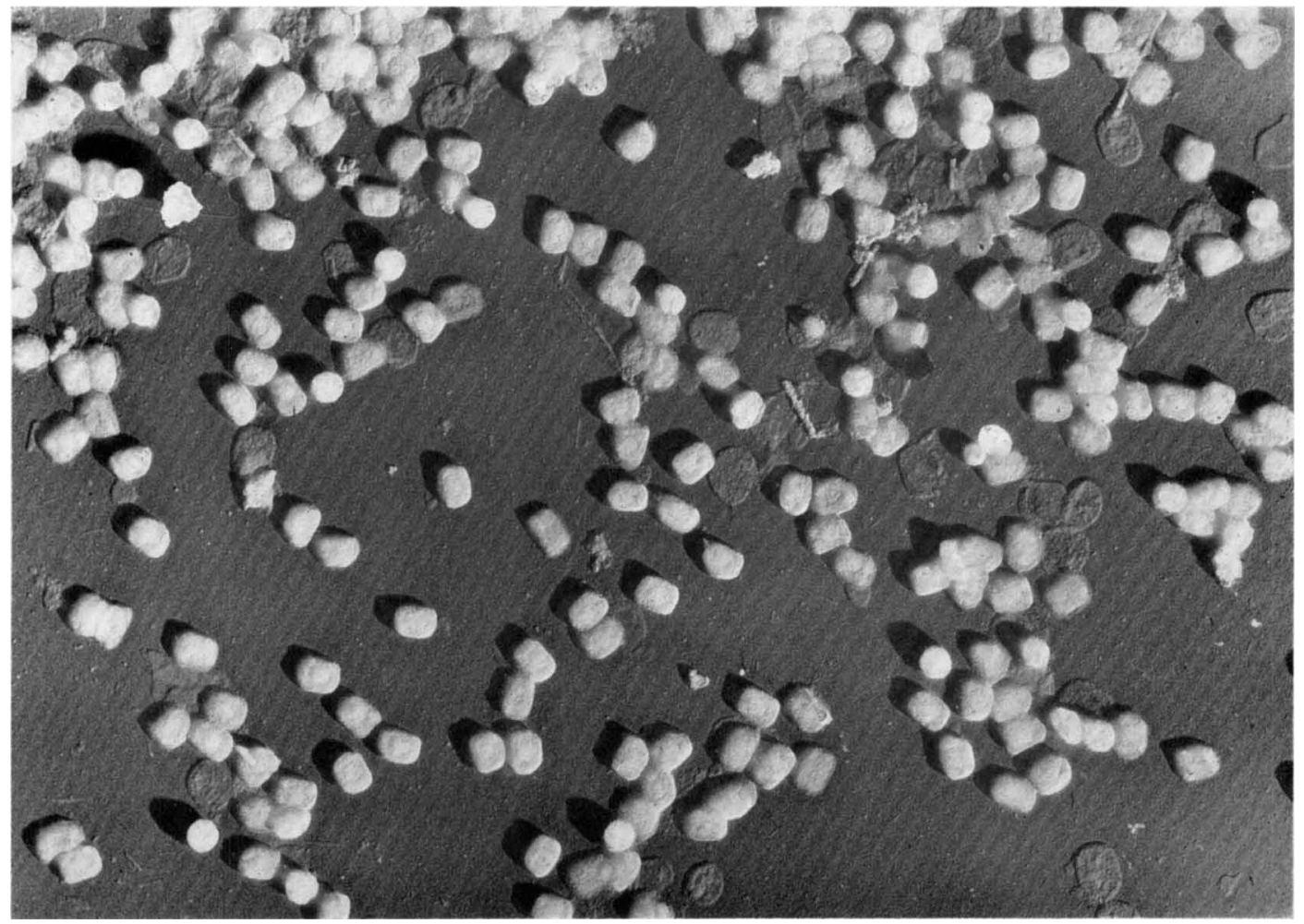

Fig. 1

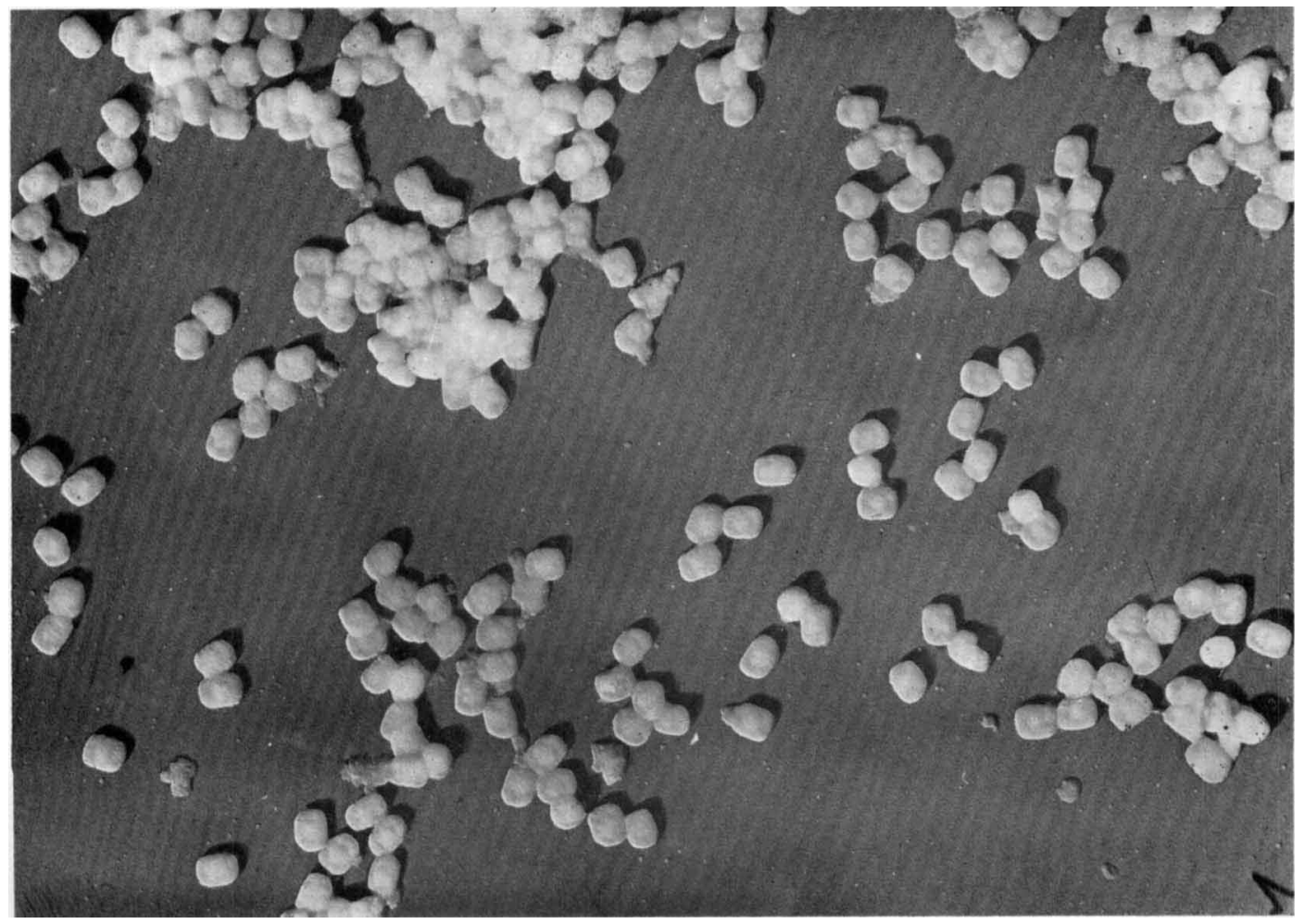

Fig. 2 



\section{REFERENCES}

BraKke, M. K. (1960). Density gradient centrifugation and its application to plant viruses. Advanc. Virus Res. 7, 193.

Craigie, J. (1932). The nature of the vaccinia flocculation reaction and observations on the elementary bodies of vaccinia. Brit. J. exp. Path. 13, 259.

Dawson, I. M. \& McFarlane, A. S. (1948). Structure of an animal virus. Nature, Lond. $161,464$.

Dumbell, K. R., Downie, A. W. \& Valentine, R. C. (1957). The ratio of the number of virus particles to infective titre of cowpox and vaccinia virus suspensions. Virology, 4, 467.

EPSTEIn, M. A. (1958). An investigation into the purifying effect of a fluorocarbon on vaccinia virus. Brit. J. exp. Path. 39, 436.

Fenner, F. (1958). The biological characters of several strains of vacinia, cowpoxand rabbitpox viruses. Virology, $5,502$.

Gessler, A. E., Bender, C. E. \& Parkinson, M. C. (1956). A new and rapid method for isolating viruses by selective fluoro-carbon deproteinization. Trans. N.Y. Acad. Sci. 18, 701.

Hoagland, C. L., Smadel, J. E. \& Rivers, T. M. (1940). Constituents of elementary bodies of vaccinia. I. Certain basic analyses and observations on lipid components of the virus. J. exp. Med. 71, 737 .

Hogeboom, G. H. \& KUfF, E. L. (1954). Sedimentation behaviour of proteins and other materials in a horizontal preparative rotor. J. biol. Chem. $210,733$.

Lowry, D. H., Rosebrough, N. J., Farr, A. L. \& Randall, R. J. (1951). Protein measurement with the Folin phenol reagent. J. biol. Chem. 193, 265.

McCrea, J. F. \& O'Loughlin, J. (1959). Separation of vaccinia haemagglutinin from infectious virus particles by chromatography on DEAE columns. Virology, 8, 127.

Smadel, J. E., Pickels, E. G. \& Shedlovsky, T. (1938). Ultracentrifugation studies on the elementary bodies of vaccine virus. II. The influence of sucrose, glycerol and urea solutions on the physical nature of vaccine virus. J. exp. Med. 68, 607.

Westwood, J. C. N., MACPherson, I. A. \& Titmuss, D. H. J. (1957). Transformation of normal cells in tissue culture: its significance relative to malignancy and virus vaccine production. Brit. J. exp. Path. 38, 138.

Westwood, J. C. N., Phipps, P. H. \& Boulter, E. A. (1957). The titration of vaccinia virus on the chorioallantoic membrane of the developing chick embryo. J. Hyg., Camb. 55, 123.

\section{EXPLANATION OF PLATE 1}

Electronmicrographs of purified pox viruses. Specimens were sprayed on to collodion supports and shadowed with gold-palladium. $\times 17,000$.

Fig. 1. Rabbit pox virus from tissue culture cells.

Fig. 2. Vaccinia virus from rabbit skin. 